\title{
Main Consequences of IFRS Adoption: Analysis of Existing Literature and Suggestions for Further Research
}

Isabel Maria Estima Costa Lourenço

Instituto Universitário de Lisboa; Departamento de Contabilidade, Lisboa, Portugal

Manuel Emílio Mota de Almeida Delgado Castelo Branco

Universidade do Porto, Faculdade de Economia, Secção de Contabilidade e Controlo de Gestão, Lisboa, Portugal

Received on 01.31.2014 - Desk acceptance on 02.04.2014 - $2^{\text {th }}$ version approved on 01.29.2015.

\begin{abstract}
This study characterizes the results of scientific research on the effect of adopting the International Financial Reporting Standards (IFRS) that have been published in the most prestigious scientific journals in the field of accounting at the international level and it identifies avenues for further research. Based on the analysis of a set of 67 articles published by the accounting journals that make up the Social Sciences Citation Index (SSCI), published between 2000 and 2013, it is concluded that, as a general rule, IFRS adoption has a positive effect on information quality, the capital market, analysts' ability to predict, comparability, and information use. Nevertheless, this effect depends on some factors, such as country's characteristics (namely, the enforcement level) and companies' characteristics. Sharing rules is not, by itself, enough to create a common business language, and management incentives and institutional factors play a major role in framing the characteristics of financial reporting. Finally, some gaps are identified in the literature and avenues for further research are introduced.
\end{abstract}

Keywords: IFRS, economic consequences, literature review, information quality. 


\section{INTRODUCTION}

As pointed out by Ball (2006), since accounting is shaped by economic and political factors, harmonization of accounting standards and practices is almost an inevitable consequence of the increasing integration of markets and policies. This has been witnessed by the mandatory adoption of the International Financial Reporting Standards (IFRS) in several countries in the last decade. Among the biggest economies in the world, only India, Japan, and the U.S. have not adopted IFRS or standards substantially converged with them, yet.

This IFRS adoption worldwide is a significant economic transformation and it gave rise to a major line of research. This article reviews the empirical literature on the effects of IFRS adoption. Empirical research allows evaluating the impact of changing standards on the financial reporting quality, as well as the effects of such a change on the capital market, it can also contribute to understanding the factors that influence the consequences of change (Pope \& McLeay, 2011). This knowledge is important for regulators in countries that are preparing to change standards, but also for regulators in countries that have already done it when considering ways to improve IFRS implementation.

The main objectives of this article are related, on the one hand, to characterizing the results of scientific research on the effect of IFRS adoption that have been published in the most prestigious scientific journals in the field of accounting at the international level and, on the other hand, with the identification of avenues for further research. In rather general terms, the research questions may be stated as follows: empirical studies published by the end of 2013 indicate predominantly positive consequences of IFRS adoption on the capital market and information quality. The conclusions differ according to the sample types used and the kinds of consequences under study.

Most studies examine the effect of IFRS adoption on information quality and the capital market, and there is a predominance of samples including a large number of countries. The results indicate that, as a general rule, IFRS adoption has a positive effect, but it depends on countries' characteristics (namely, the enforcement level) and companies' characteristics. Sharing rules is not, by itself, enough to create a common business language, and management incentives and institutional factors play a major role in framing the characteristics of financial reporting. It has been particularly detected that when using samples that include countries from various continents, the results are not as favorable regarding IFRS adoption when compared to samples that include only countries in the European Union (EU).

This study contributes to the literature by means of an analysis of studies addressing the consequences of IFRS adoption published so far by journals in the field of accounting regarded as "top". Unlike literature reviews already published, we consider only actual research, validated through outstanding peer review, rather than concentrating on all studies conducted (published or not). Based on the analysis of existing literature, we also introduce avenues for further research.

Sections 2 and 3 provide a framing of the theme and characterize the methodology used in this study. Then, the results are shown and discussed and, finally, a summary of the study carried out and its main conclusions are presented.

\section{FRAMING}

\subsection{Generalized IFRS adoption.}

The International Accounting Standards Board (IASB) is a private organization of international scope established in 1973 and headquartered in London. It has issued a set of standards to be used when preparing financial statements, namely 41 International Accounting Standards (IAS) and 13 International Financial Reporting Standards (IFRS). IAS are standards issued by the IASB by 2001 and IFRS are standards issued after that year. Nevertheless, currently, the expression IFRS is commonly used alone to designate this set of rules (IAS and IFRS).

The number of countries to allow and/or require IFRS adoption when preparing financial statements has grown over the last years. The year 2005 has become a particularly significant milestone in terms of mandatory IFRS adoption, since this was the year that it took place in the EU and Australia.
The EU Regulation 1606/2002 established that all companies listed on the stock exchange in any EU country start to prepare, from the accounting period beginning on or after January 1, 2005, their consolidated financial statements in accordance with IFRS, approved by the EU Commission. In Australia, there came into force, since 2005, standards regarded as completely equivalent to IFRS (Zeff \& Nobes, 2010). Contrary to what has occurred in the EU, where IASB standards were accepted just as issued by this organization, albeit with some deletions, in Australia occurred, namely, change in the standards names, some textual changes, and deletion of some options, and this has led to documents clearly different from the original as issued by the IASB.

IFRS adoption in the EU is taken as a particularly relevant event. One of its effects will be the considerable increase in the credibility of the IASB project worldwide 
(Pope \& McLeay, 2011). The decision to adopt IFRS in the EU played a key role in the international acceptance and dissemination of IFRS (Brown, 2013).

The year 2010 was a second significant milestone in the IFRS adoption process worldwide, with mandatory adoption in Brazil, a country of great importance for the global economy. Later, other countries with great economic importance adopted IFRS: in 2011, Canada; in 2012, Mexico and Russia.

\subsection{The effect of IFRS adoption.}

Van Tendeloo and Vanstraelen (2005) point out four advantages resulting from IFRS adoption. First, such adoption will trigger greater investors' ability to make informed financial decisions, eliminating confusion that arises from the existence of different ways to measure status and financial performance in different countries, leading to reduced risk for investors and lower cost of capital for companies. Second, it will lead to reduced costs related to preparation of financial information according to several sets of standards. Third, it will lead to greater incentives for international investment. Fourth, it will allow a more effective allocation of financial resources worldwide.

Particularly, when compared to accounting systems that are significantly influenced by political and fiscal issues, such as that prevailing for a long time in Continental Europe by 2005, the system based on IFRS will provide several advantages. According to Ball (2006), a system based on IFRS not only better reflects the economic substance of transactions than their legal form, but it also reflects economic gains and losses in a more timely or appropriate manner. In addition, still according to Ball (2006), such a system makes the results more informative, it allows providing better accounting information and reduces the discretion that the traditional accounting system existing in Continental Europe provided managers with in order to manipulate provisions, create hidden reserves, embellish outcomes, and conceal economic losses.

In most countries, IFRS adoption is associated with a significant paradigm shift. The application of a set of rules gives room to the application of a set of principles aimed at providing useful information to make economic decisions. IFRS adoption is associated with an increased complexity in the accounting system, which now requires a higher degree of assessment and greater commitment of managers at various levels within the company and it is also characterized by a move away from accounting towards taxation and a significant increase in the amount of disclosure. Nevertheless, it is expected that the benefits resulting from IFRS adoption are higher than the costs associated with this paradigm shift.

One of the main arguments used in favor of IFRS adoption is that this set of standards enables obtaining better information, as a result of using recognition and measurement criteria that better reflect the economic reality of companies and providing a wide range of in- formation in the notes. The widespread IFRS adoption at the international level also allows increasing the comparability of financial statements.

It is expected that the increased quality and comparability of financial statements, and the consequent increased usefulness of information, have a positive impact on the prediction amount and ability of analysts who follow up companies on the capital market, the credit market, on executive pay, and on economic decisions made by companies. Thus, IFRS adoption will lead to improved investors' ability to make informed financial decisions, improved investment and/or funding conditions, and an effective allocation of financial resources worldwide.

Other arguments in favor of IFRS adoption, referred to less frequently, include access to accounting standardization competences that do not exist in the country, sharing of accounting standard costs, and increased accounting professionals mobility in the labor market (Brown, 2013).

Despite the advantages usually associated with convergence to IFRS, the effect of adopting this set of standards is still a matter of debate (Hail, Leuz, \& Wysocki, 2010a, 2010b; Christensen, 2012). There are reasons to believe that IFRS adoption, by itself, does not guarantee an increased information quality and comparability and a consequent improvement in the allocation of financial resources worldwide. Using the same rules is a necessary, but not sufficient, condition to create a common language of financial information disclosure (Jeanjean \& Stolowy, 2008). Manager incentives and institutional factors may also play a major role in determining the characteristics of financial statements. There are, today, some consensus around the idea that strict enforcement mechanisms and reporting incentives are indispensable to make the benefits of IFRS adoption come true (e.g. Kaya \& Pillhofer, 2013; Barth, Landsman, Lang, \& Williams, 2012; Brown, 2013; Leuz, 2010; Ball, 2006). Another aspect not often mentioned, but stressed by Brown (2011), is related to the importance of training staff directly involved in the production of financial information.

Hail et al. (2010a, 2010b) have analyzed the possible IFRS adoption in the U.S. and they conclude that this involves a commitment between: (i) transition costs for companies, which will be short-term; (ii) positive effects related to comparability, which will be obtained over a much longer period; and (iii) reporting cost reductions, mainly obtained by multinationals (Hail et al., 2010a).

One of the features of U.S. GAAP, when compared to IFRS, is providing a smaller range of choice and greater focus, and many people think that this leads the current standards in the US to have a better quality (Hail et al., 2010a). As IFRS have options and require value assessment and value judgments, it is inevitable that there is some disparity in the way how they are applied. Misusing this room for maneuver depends on companies' characteristics (e.g. financial incentives for transparency of infor- 
mation) and countries' institutional characteristics (e.g. enforcement level). Therefore, IFRS adoption will not benefit uniformly those with a potential interest in applying this set of standards. There will be, of course, winners and losers in this process of convergence to IFRS.

\subsection{Literature reviews on the effect of IFRS adoption.}

IFRS adoption at the international level has been, in recent years, one of the issues more frequently analyzed and discussed in the accounting field, generating interest among professionals, scholars, investors, and other users of financial information.

Many studies have examined the consequences of IFRS adoption. After several years of empirical analysis, some literature reviews on the subject were published by journals in the accounting field. Although there are some articles that provide interesting literature analyses, such as Brown $(2011,2013)$ and the Hail et al. (2010a, 2010b), few of them offer a systematic review on the theme: Soderstrom and Sun (2007), Pope and McLeay (2011), Brüggemann, Hitz and Sellhorn (2013), Palea (2013), and Ahmed, K., Chalmers and Khlif (2013), in English; and Calixto (2010), in Portuguese. Out of them, only the article by Ahmed, K. et al. (2013) has a scope going beyond IFRS adoption in the EU.

Sodestrom and Sun (2007) mainly focused on the analysis of studies addressing the impact of voluntary IFRS adoption in the EU. They emphasize the strong influence of the institutional context in the accounting information quality and warn about the impossibility to generalize outcomes regarding voluntary IFRS adoption for its mandatory adoption.

Pope and McLeay (2011) have analyzed studies on mandatory IFRS adoption in the EU, but they focus on those conducted within the project INTACCT (The European IFRS Revolution: Compliance, Consequences and Policy Lessons - funded by the EU). They also emphasize that the effects of mandatory IFRS adoption are not uniform in the EU, as a result of differences in preparers' incentives and local enforcement mechanisms.

Brüggemann et al. (2013) also analyze studies on IFRS adoption in the EU, but they consider three categories of consequences: in financial reporting in the capital market, and those with a macroeconomic nature. These authors also introduce the distinction between intended and unintended economic consequences, depending on whether they are related to regulator's stated objectives. They stress that IFRS had a limited effect on financial reporting, due to a substantial non-compliance, persistence of national accounting standards of choice, and absence of improvement regarding transparency of outcomes and comparability measurements. On the other hand, they detected strong evidence that mandatory IFRS adoption brought macroeconomic benefits and benefits for the capital market.

Palea (2013) has also examined the effects of IFRS adoption in the EU in terms of financial reporting quality, focusing on the investigation about the relevant value. The author concluded that empirical evidence points out a positive effect of mandatory IFRS adoption in the EU and that these effects differ depending on the institutional contexts of companies adopting such standards. The persistence of national differences after IFRS adoption is also pointed out.

Calixto (2010) has analyzed the studies on IFRS adoption in the EU, but not limited to economic consequences. The author also analyzed, for instance, studies on opinions about IFRS implementation. It was concluded, among other things, that the studies on the impacts of IFRS adoption still have limited results, largely due to the fact that legal requirement of IFRS adoption is very recent.

Ahmed, K. et al. (2013) have conducted a meta-analysis of studies on the effect of IFRS adoption on information quality, measured as value relevance and discretionary accruals, and on analysts' prediction quality. Their results suggest: absence of a relevant increase in the value of equity and a reduction in discretionary accruals; the existence of a significant increased value in the results, when assessed by pricing models; and improved prediction of outcomes by financial analysts.

Our study has three differences when compared to the papers mentioned. On the one hand, it addresses studies on the consequences of IFRS adoption not only in the EU but also in other geographical areas, such as Asia and Oceania (Australia and New Zealand), enabling a different analysis considering the countries that adopted IFRS. On the other hand, it analyzes a much broader range of consequences. Finally, it focuses only on articles published by top journals in the accounting field.

\section{METHODOLOGY}

This study aims to characterize the results of scientific research on the effect of IFRS adoption that have been published by the most prestigious scientific journals in the accounting field at the international level and identify avenues for further research.

We considered the journals included in the Social Sciences Citation Index (SSCI), a database developed by the multinational news agency Thomson Reuters. This index tracks article citations in about 3,000 top scientific journals in the various social sciences disciplines, among them accounting, and it assumes that the number of citations reflect the impact of an article. The SSCI is very significant worldwide, there are some countries where it is used to assess the performance of a researcher, determining her/his career development and public funding (Parker \& Guthrie, 2013). 
A few years ago, it was argued that the SSCI could not be used as a reference in the accounting field, due to the small number of journals included in this index (Chan \& Liano, 2009). Today, this argument is not regarded as valid anymore, since many accounting journals have been included in this index in recent years. In 2012, the number of accounting journals included in the SSCI amounted to 20, something quite reasonable.

Table 1 identifies the 20 accounting journals included in the SSCI in 2012 and it provides information on the impact factor and the country to which each journal is associated. The Journal of International Financial Ma- nagement and Accounting (JIFMA) is the only one that is not associated with any specific country(ies), since this is a journal of the International Association of Accounting and Educational Research, so it is difficult to establish this association.

Thomson Reuters annually produces the Journal Citation Reports (JCR), which allow assessing and comparing journals. These reports have a measurement that reflects the average number of article citations published by the journals covered by the SSCI, the impact factor (IF). Since the IF refers to a time period, Thomson Reuters discloses the annual IF and the IF within a 5-year period.

Table 1 Accounting journals included in the Social Sciences Citation Index

\begin{tabular}{|c|c|c|c|}
\hline Journal & Country(ies) & Impact factor & $\begin{array}{c}\text { 5-year impact } \\
\text { factor }\end{array}$ \\
\hline Abacus & Australia & 0.850 & 1.010 \\
\hline Accounting, Auditing and Accountability Journal (AAAJ) & Australia & 0.922 & - \\
\hline Accounting and Business Research (ABR) & United Kingdom & 0.533 & 0.792 \\
\hline Accounting and Finance (A\&F) & Australia & 0.875 & 0.794 \\
\hline Accounting Horizons $(\mathrm{AH})$ & U.S. & 1.288 & - \\
\hline Accounting Organizations and Society (AOS) & United Kingdom & 1.867 & 3.143 \\
\hline Accounting Review (AR) & U.S. & 2.319 & 3.204 \\
\hline Asia-Pacific Journal of Accounting and Economics (APJAE) & Hong Kong and Taiwan & 0.206 & - \\
\hline Auditing: a Journal of Practice and Theory (AJPT) & U.S. & 1.015 & 1.408 \\
\hline Contemporary Accounting Research (CAR) & Canada & 1.564 & 2.154 \\
\hline European Accounting Review (EAR) & Europe & 0.654 & 1.465 \\
\hline Journal of Accounting and Economics (JAE) & U.S. & 3.912 & 4.023 \\
\hline Journal of Accounting and Public Policy (JAPP) & U.S. & 0.770 & - \\
\hline Journal of Accounting Research (JAR) & U.S. & 2.192 & 3.368 \\
\hline Journal of Business Finance and Accounting (JBFA) & United Kingdom & 1.010 & 1.061 \\
\hline Journal of International Financial Management and Accounting (JIFMA) & - & 0.333 & - \\
\hline Management Accounting Research (MAR) & United Kingdom & 1.366 & - \\
\hline Review of Accounting Studies (RAS) & Canada & 1.364 & 1.899 \\
\hline Spanish Journal of Finance and Accounting (SJFA) & Spain & 0.106 & - \\
\hline
\end{tabular}

Source: Prepared by the authors.

As displayed in Table 1,8 out of the 20 journals have only the annual IF, due to the factor they have entered the list recently: AAAJ; AH; APJAE; AAR; JAPP; JIFMA; MAR; and SJFA. Among these recent entries, 3 are "regional" journals (APJAE, AAR, and SJFA), 2 out of these 3 journals are published by or on behalf of professional associations (AAR belongs to CPA Australia; SJFA belongs to the Spanish Association of Accounting and Business Administration).

The 6 journals with higher 5-year IF are included in the list of 45 journals used by the newspaper Financial Times to assess the MBA programs of the best business schools in the world: AOS, AR, CAR, JAE, JAR, and RAS. These journals are regarded as the most influential in the accounting field (Bonner, Hesford, Van der Stede, \& Young, 2006; Chan \& Liano, 2009).
To achieve the objective of this study, we referred to the journals listed in Table 1 and the articles published by December 2013 were analyzed. We identified $67 \mathrm{stu}-$ dies that empirically analyze the effect of IFRS adoption. Table 2 shows the distribution of these articles per journal and year of publication.

We identified articles on the effect of IFRS adoption in all of the journals under analysis, except for AAAJ, AOS, Auditing, and MAR, where the absence of this kind of article is not a matter of surprise, as they are journals devoted to other areas than financial accounting.

Despite the importance of IFRS adoption in Europe and Australia, since 2005, European and Australian journals are those with fewer articles addressing the 
effect of IFRS adoption, respectively, $15 \%$ and $18 \%$ of the total. The articles are evenly distributed over the period within 2005 and 2013.

Despite IFRS are not applied in the U.S., U.S. journals are those having a greater number of articles published (60\%), mainly from 2007 on and showing a marked increase from 2010 on. Such a temporal evolution is related to the process of getting closer to IFRS that took place in the U.S. In 2007, the Securities and Exchange
Commission (SEC) decided to annul the requirement to reconcile financial statements to U.S. GAAP by foreign companies with financial statements prepared in accordance with IFRS (Securities and Exchange Commission, 2007). In 2008, the SEC published for comment a document on the possible steps to be taken for IFRS adoption in the U.S. (Securities and Exchange Commission, 2008). These events will stimulate further research carried out in the U.S. on the theme of IFRS adoption.

\begin{tabular}{|c|c|c|c|c|c|c|c|c|c|c|c|c|c|c|c|}
\hline Journals & 2000 & 2001 & 2002 & 2003 & 2004 & 2005 & 2006 & 2007 & 2008 & 2009 & 2010 & 2011 & 2012 & 2013 & Total \\
\hline \multicolumn{16}{|l|}{ U.S. } \\
\hline $\mathrm{AH}$ & & & & & & & & & & & 1 & 2 & & 1 & 4 \\
\hline AR & & & & & & & & & & & 2 & & 3 & 4 & 9 \\
\hline CAR & & & & & & & & & & & & & & 3 & 3 \\
\hline JAE & & & & & & & & & & & & 1 & 2 & 1 & 4 \\
\hline JAPP & 1 & & & & & & & & 1 & & & 2 & 2 & & 6 \\
\hline JAR & & 1 & & 1 & & & & 1 & 2 & 1 & & 2 & 1 & 1 & 10 \\
\hline \multirow[t]{2}{*}{ RAS } & & & & & & & & 1 & & & 1 & 1 & 1 & & 4 \\
\hline & 1 & 1 & 0 & 1 & 0 & 0 & 0 & 2 & 3 & 1 & 4 & 8 & 9 & 10 & 40 \\
\hline \multicolumn{16}{|c|}{ European } \\
\hline ABR & & & & & & & & & & 1 & & & & & 1 \\
\hline EAR & & & & & & 1 & & & & & 1 & & & 1 & 3 \\
\hline JBFA & & & & & & & 1 & & & 1 & & 1 & & 1 & 4 \\
\hline \multirow[t]{2}{*}{ SJFA } & & & & & & & & & 1 & & & & 1 & & 2 \\
\hline & 0 & 0 & 0 & 0 & 0 & 1 & 1 & 0 & 1 & 2 & 1 & 1 & 1 & 2 & 10 \\
\hline \multicolumn{16}{|c|}{ Australian and Asian } \\
\hline$A \& F$ & & & & & & & & & & 1 & 1 & & 3 & & 5 \\
\hline AAR & & & & & & & & & 1 & 1 & 1 & 1 & & & 4 \\
\hline Abacus & & & & & & & 1 & & & & & & & 2 & 3 \\
\hline \multirow[t]{2}{*}{ APJAE } & 1 & & & & & & & & & & & & & & 1 \\
\hline & 1 & 0 & 0 & 0 & 0 & 0 & 1 & 0 & 1 & 2 & 2 & 1 & 3 & 2 & 13 \\
\hline \multicolumn{16}{|l|}{ Others } \\
\hline Total & 2 & 1 & 0 & 1 & 0 & 1 & 2 & 3 & 5 & 5 & 9 & 11 & 13 & 14 & 67 \\
\hline
\end{tabular}

The studies referred to in Table 2 were classified according to the nature of the effect of IFRS adoption, especially on information quality, information comparability, information cost, analysts, the capital and/or credit market, and information use. Finally, the results obtained by the studies classified in each of these categories are characterized and clues for further research are identified.

\section{RESULTS OBTAINED}

Table 3 displays the distribution of articles analyzed depending on the nature of the effect of IFRS adoption. Most studies examine the effect of IFRS adoption on information quality (39\%) and the capital and/or credit market (39\%). Nevertheless, in U.S. journals, there is a predominance of studies addressing the effect of adop- tion on the capital and/or credit market, contrary to the other journals, dominated by studies addressing the effect of IFRS adoption on information quality.

In U.S. journals there is also a significant difference between those more influential (Chan \& Liano, 2009), having a higher impact factor (AR, JAE, JAR, and RAS), and 
the other ones. While the first publish a greater number of articles addressing the effect of IFRS adoption on the capital market and/or have greater diversification in terms of themes, the other ones mostly publish, articles addressing the effect of IFRS adoption on information quality, just as observed regarding journals that are not from the U.S.

Table 3 Distribution of articles according to the nature of the effect of IFRS adoption

\begin{tabular}{|c|c|c|c|c|c|c|c|}
\hline Journals & $\begin{array}{l}\text { Information } \\
\text { quality }\end{array}$ & $\begin{array}{c}\text { Capital/credit } \\
\text { market }\end{array}$ & Analysts & $\begin{array}{l}\text { Information } \\
\text { comparability }\end{array}$ & $\begin{array}{c}\text { Information } \\
\text { cost }\end{array}$ & $\begin{array}{c}\text { Information } \\
\text { use }\end{array}$ & Total \\
\hline \multicolumn{8}{|l|}{ U.S. } \\
\hline $\mathrm{AH}$ & 2 & 2 & & & & & 4 \\
\hline $\mathrm{AR}$ & & 5 & & 1 & 2 & 1 & 9 \\
\hline CAR & 1 & 1 & 1 & & & & 3 \\
\hline JAE & & 3 & & 1 & & & 4 \\
\hline JAPP & 4 & 2 & & & & & 6 \\
\hline JAR & 1 & 5 & 3 & & & 1 & 10 \\
\hline \multirow[t]{2}{*}{ RAS } & 1 & 3 & & & & & 4 \\
\hline & 9 & 21 & 4 & 2 & 2 & 2 & 40 \\
\hline \multicolumn{8}{|c|}{ European } \\
\hline EAR & 2 & & 1 & & & & 3 \\
\hline JBFA & 2 & 2 & & & & & 4 \\
\hline \multirow[t]{2}{*}{ SJFA } & 1 & 1 & & & & & 2 \\
\hline & 5 & 3 & 1 & 1 & 0 & 0 & 10 \\
\hline \multicolumn{8}{|c|}{ Australian and Asian } \\
\hline$A \& F$ & 1 & 1 & 2 & & 1 & & 5 \\
\hline AAR & 4 & & & & & & 4 \\
\hline Abacus & 2 & 1 & & & & & 3 \\
\hline \multirow[t]{2}{*}{ APJAE } & 1 & & & & & & 1 \\
\hline & 8 & 2 & 2 & 0 & 1 & 0 & 13 \\
\hline \multicolumn{8}{|l|}{ Others } \\
\hline Total & 26 & 26 & 7 & 3 & 3 & 2 & 67 \\
\hline
\end{tabular}

\subsection{Effect of IFRS adoption on information quality.}

The journals under analysis have published fourteen studies showing empirical evidence that IFRS adoption has a positive effect on information quality. It is understood that there is a positive effect when the information disclosed in accordance with IFRS has higher quality (higher relevant value, lower level of outcome management, etc.) than when it was disclosed in accordance with local standards.

These studies analyze the effect of IFRS adoption by Australian companies (Taylor, Tower, \& Neilson, 2010; Taylor \& Tower, 2011; Clacher, Ricquebourg, \& Hodgson, 2013), by UK companies (Choi, Peasnell, \& Toniato, 2013), by Finnish companies (Niskanen, Kinnunen, \& Kasanen, 2000), by German companies (Jermakowicz, Prather-Kinsey, \& Wulf, 2007), by European companies (Daske \& Gebhardt, 2006; Morais \& Curto, 2009; Aha- rony, Barniv, \& Falk, 2010; Chen, Tang, Jiang, \& Lin, 2010; Gebhardt \& Novotny-Farkas, 2011), by U.S. companies (McAnally, McGuire, \& Weaver, 2010), and by companies from various countries in the world (Barth, Landsman, \& Lang, 2008; Sun, Cahan, \& Emanuel, 2011).

Two of these studies also provide empirical evidence that the companies' characteristics, countries' characteristics, and differences between local standards and IFRS are factors that affect the effect of IFRS adoption on information quality. This effect is greater on companies having al greater capital dispersion and shares listed for trade on the U.S. and on countries with greater surveillance (Gebhardt \& Novotny-Farkas, 2011). The effect is also greater on countries with more significant differences between local standards and IFRS (Aharony et al., 2010).

The journals under analysis have also published six studies showing empirical evidence that IFRS adoption by Australian companies (Chalmers, Clinch, \& Godfrey, 
2008), by European companies (Devalle, Onali, \& Magarini, 2010; Aubert \& Grudnitski, 2011), and by companies from various countries in the world (Lara, Torres, \& Veira, 2008; Jeanjean \& Stolowy, 2008; Atwood, Drake, Myers, \& Myers, 2011) has a mixed effect on information quality. It is understood that there is a mixed effect when IFRS adoption has a positive (or negative) effect in some cases and a negative or null effect in the other cases.

Thus, Lara et al. (2008) show that IFRS adoption has a positive effect on companies in the European countries, having greater enforcement, but it has no effect on companies in developing countries. Chalmers et al. (2008) demonstrate that IFRS adoption has a positive effect on the relevant value of goodwill and a negative effect on the relevant value of identifiable intangible assets.

The studies analyzing European companies demonstrate that IFRS adoption has a positive effect on companies in some European countries and a negative (Devalle et al., 2010) or null effect (Aubert \& Grudnitski, 2011) on companies in other countries within the same economic space. The remaining studies demonstrate that IFRS adoption has a negative effect on a specific group of companies and null on another one, especially companies applying U.S. GAAP versus companies applying other local regulations (Atwood et al., 2011) and French versus Australian companies and UK companies (Jeanjean \& Stolowy, 2008).

The journals under analysis have also published four studies that show empirical evidence that IFRS adoption by New Zealand companies (Kabir, Laswad, \& Ainul Islam, 2010), by German companies (Van Tendeloo \& Vanstraelen, 2005; Hung \& Subramanyam, 2007), and by Chinese companies (Ball, Robin, \& Wu, 2000) has a null effect on information quality. Information quality is the same, regardless of whether IFRS or local standards were applied.

Finally, the journals under analysis have also published two studies showing empirical evidence that IFRS adoption by German companies (Lin, Riccardi, \& Wang, 2012) and by companies from various countries in the world (Ahmed, A., Neel, \& Wang, 2013) has a negative effect on information quality. Thus, it becomes clear that information has a lower quality when prepared in an IFRS environment than when prepared in accordance with local standards.

\subsection{IFRS adoption effect on the capital and/or credit markets.}

The journals under analysis have published sixteen studies showing empirical evidence that IFRS adoption has a positive effect on the capital market. It is understood that there is a positive effect when IFRS adoption improves operating conditions in the capital market, because it leads to lower cost of capital, lower synchronicity of actions, attraction of institutional investors and foreign investors, including others.

These studies analyze the effect of IFRS adoption by Australian companies (Bissessur \& Hodgson, 2012), by UK companies (Christensen, Lee, \& Walker, 2009; Horton \& Serafeim, 2010; Brochet, Jagolinzer, \& Riedl, 2013), by Italian companies (Frino, Palumbo, Capalbo, Gerace, \& Mollica, 2013), by European companies (Armstrong, Barth, Jagolinzer, \& Riedl, 2010; Platikanova \& Perramon, 2012), by U.S. companies (Joos \& Leung, 2013), and companies from various countries in the world (Covrig, DeFond, \& Hung, 2007; Karamanou \& Nishiotis, 2009; Khurana \& Michas, 2011; Florou \& Pope, 2012; Kim \& Shi, 2012; Landsman, Maydew, \& Thornock, 2012; Hong, 2013; Christensen, Hail, \& Leuz, 2013).

Nine of these studies also provide empirical evidence that the differences between local standards and IFRS, change in information transparency and/or the comparability, countries and companies' characteristics are factors affecting the effect of IFRS adoption on the capital market. This effect is greater on companies from countries with more significant differences between local standards and IFRS (Khurana \& Michas, 2011; Florou \& Pope, 2012), on companies that are expected to have a greater increase in information transparency and/or comparability (Joos \& Leung, 2013; Hong, 2013; Brochet et al., 2013), on companies from countries with a higher enforcement level (Kim \& Shi, 2012; Florou \& Pope, 2012; Landsman et al., 2012, Hong, 2013; Christensen et al., 2013), and on companies from Common Law countries (Khurana \& Michas, 2011; Armstrong et al., 2010).

As for companies' characteristics, it was found that the effect of IFRS adoption on the capital market is greater on companies with lower information quality before IFRS adoption (Armstrong et al., 2010), on companies with greater incentives to report with transparency (Karamanou \& Nishiotis, 2009; Armstrong et al., 2010), on companies with lower risk of litigation (Joos \& Leung, 2013), and on companies with higher risk of non-compliance with debt covenants (Christensen et al., 2009). There is also evidence that the effect of IFRS adoption is greater on companies less frequently followed up by analysts (Kim \& Shi, 2012) and on smaller companies with less visibility, when the analysis perspective is attracting foreign investors (Covrig et al., 2007).

The journals under analysis have also published two studies showing empirical evidence that IFRS adoption by companies from various countries in the world have a positive effect on the credit market, especially in terms of cost and nature of loans and attracting foreign creditors (Kim, Tsui, \& Yi, 2011) and credit ratings (Ling-Ching, Hsu, \& Lee, 2013).

The journals under analysis have also published six studies demonstrating that IFRS adoption by European companies $(\mathrm{Li}, 2010)$ and by companies from various countries in the world (Daske, Hail, Leuz, \& Verdi, 2008; DeFond, Hu, Hung, \& Li, 2011; Shima \& Gordon, 2011; Gordon, Loeb, \& Zhu, 2012; Daske, Hail, Leuz, \& Verdi, 2013) has a mixed effect on the capital market. These studies demonstrate that IFRS adoption has a positive effect on a specific group of companies and a null effect on the other ones.

The positive effect is observed on companies applying IFRS as part of a strategy to increase commitment to transparency, named as serious vs. label adopters (Daske et al., 2013), on companies where there was 
a significant increase in information comparability (DeFond et al., 2011), on companies from countries with a high enforcement (Daske et al., 2008; Li, 2010; Shima \& Gordon, 2011), and on companies in developing countries (Gordon et al., 2012), however, when the analysis perspective is attracting foreign investors. Li (2010) also demonstrates that variations in information quality and comparability positively affect the effect of IFRS adoption on countries with a high enforcement level.

The journals under analysis have also published two studies showing empirical evidence that IFRS adoption by German companies (Leuz, 2003; Daske, 2006) has a null effect on the capital market. The cost of capital is the same, regardless of whether applying IFRS or local standards.

\subsection{Effect of IFRS adoption on analysts.}

The journals under analysis have published six studies showing empirical evidence that IFRS adoption has a positive effect on analysts. It is understood that there is a positive effect when IFRS adoption, rather than local standards, leads to an increased analysts' ability to predict.

These studies analyze the effect of IFRS adoption by Australian companies (Chalmers, Clinch, Godfrey, \& Wei, 2012; Cotter, Tarca, \& Wee, 2012), by German companies (Glaum, Baetge, Grothe, \& Oberdörster, 2013), by European companies (Byard, Li, \& Yu, 2011), and companies from various countries in the world (Ashbaugh \& Pincus, 2001; Horton, Serafeim, \& Serafeim, 2013).

Four out of these studies also provide empirical evidence that the differences between local standards and IFRS, variation in information quality and comparability, countries and companies' characteristics are factors affecting the effect of IFRS adoption on analysts' ability to predict. This effect is greater on companies from countries with significant differences between local standards and IFRS (Ashbaugh \& Pincus, 2001; Byard et al., 2011; Horton et al., 2013), on companies where there was a greater increase in information quality (Horton et al., 2013; Glaum et al., 2013), and on information comparability (Horton et al., 2013), in companies from countries with a high enforcement level, and on companies with greater incentives to report transparently (Byard et al., 2011).

However, the journals under analysis have also published a study showing empirical evidence that IFRS adoption by companies from various countries in the world has a positive effect on foreign analysts' ability to predict, but not on national analysts, and on attracting new analysts, foreign and national (Tan, Wang, \& Welker, 2011). This study also demonstrates that the differences between local standards and IFRS and analysts' experience with IFRS are factors that affect attracting new analysts. The first factor is particularly significant in attracting foreign analysts.

\subsection{Effect of IFRS adoption on information comparability.}

The journals under analysis have published two studies showing empirical evidence that IFRS adoption has a positive effect on information comparability. It is un- derstood that there is a positive effect when information is more comparable in an IFRS environment than when local standards are applied.

One of these studies examines the effect of IFRS adoption on information comparability between companies from different European countries (Yip \& Young, 2012). Another study examines the effect of IFRS adoption on information comparability between non-U.S. companies and U.S. companies (Barth et al., 2012).

These two studies also provide empirical evidence that countries' characteristics and the way how IFRS are adopted (voluntary vs. mandatory) are factors that affect the effect of IFRS adoption on information comparability. The increase in information comparability is higher among companies from European countries with the same legal system (Yip \& Young, 2012). Besides, increased comparability with U.S. companies is higher among non-U.S. companies from Common Law countries and countries with a high enforcement level and among non-U.S. companies applying IFRS on a mandatory basis (Barth et al., 2012).

Nevertheless, the journals under analysis have also published a study showing empirical evidence that IFRS adoption has a mixed effect on information comparability of European companies with securities listed to trading on the U.S., disclosed in accordance with IFRS vs. U.S. GAAP (Gray, Linthicum, \& Street, 2009). For companies that adopted IFRS on a mandatory basis in 2005 , the effect on comparability is negative, contrary to the companies that adopted IFRS voluntarily before 2005, where a null effect is observed.

\subsection{Effect of IFRS adoption on information cost.}

The journals under analysis have published three studies showing empirical evidence that IFRS adoption has a negative effect on information cost. It is understood that there is a negative effect when IFRS adoption leads to an increase in costs for companies, particularly regarding audit fees. These studies examine the effect of IFRS adoption by New Zealand companies (Griffin, Lont, \& Sun, 2009), by Australian companies (De George, Ferguson, \& Spear, 2013), and by European companies (Kim, Liu, \& Zheng, 2012).

Two of these studies also provide empirical evidence that companies' characteristics, countries' characteristics, and the differences between local standards and IFRS are factors that affect the effect of IFRS adoption on information cost. This achievement is greater in companies subject to a more complex auditing process (De George et al., 2013) and in countries with a lower enforcement level and having more significant differences between local standards and IFRS (Kim et al., 2012).

\subsection{Effect of IFRS adoption on information use.}

The journals under analysis have published two studies showing empirical evidence that IFRS adoption has a positive effect on information use, to the extent that the accounting information prepared according to IFRS is seen as having higher quality and, as a consequence, it is more frequently used in executive pay (Ozkan, Singer, \& You, 2012) and in decision making on investment (Chen, Young, \& Zhuang, 2013). 
These studies also provide evidence that the effect of IFRS adoption on information use is greater in countries with more significant differences between local standards and IFRS and companies whose activity has an international nature and having few national com- panies in the same industry and having the same size (Ozkan et al., 2012). The effect is also greater on rather competitive industries and where competitors are located in foreign countries with a high enforcement level (Chen et al., 2013).

\section{SUMMARY AND DISCUSSION OF RESULTS}

Table 4 summarizes the results of studies under analysis, whose distribution depends on the sample used, the nature of the effect, and the meaning of the effect in IFRS adoption.

Most studies examine the effect and meaning of IFRS adoption by using a sample of several countries, either from different continents or only countries within the European space. There are also few studies on Australia, predominantly published by Australian journals. Studies on Germany essentially analyze the effect of voluntary IFRS adoption before 2005 .

Table 4 Distribution of articles according to the sample used, the nature of the effect, and the meaning of the effect in IFRS adoption

\begin{tabular}{|c|c|c|c|c|c|c|c|c|c|c|c|}
\hline Journals & Multicontinental & Europe & Australia & Germany & UK & U.S. & $\begin{array}{c}\text { New } \\
\text { Zealand }\end{array}$ & Finland & Italy & China & Total \\
\hline \multicolumn{12}{|c|}{ Information quality } \\
\hline Positive effect & 2 & 5 & 3 & 1 & 1 & 1 & & 1 & & & 14 \\
\hline Negative effect & 1 & & & 1 & & & & & & & 2 \\
\hline Mixed effect & 3 & 2 & 1 & & & & & & & & 6 \\
\hline \multirow[t]{2}{*}{ Null effect } & & & & 2 & & & 1 & & & 1 & 4 \\
\hline & 6 & 7 & 4 & 4 & 1 & 1 & 1 & 1 & 0 & 1 & 26 \\
\hline \multicolumn{12}{|c|}{ Capital/credit market } \\
\hline Positive effect & 11 & 2 & 1 & & 2 & 1 & & & 1 & & 18 \\
\hline Mixed effect & 5 & 1 & & & & & & & & & 6 \\
\hline \multirow[t]{2}{*}{ Null effect } & & & & 2 & & & & & & & 2 \\
\hline & 16 & 3 & 1 & 2 & 2 & 1 & 0 & 0 & 1 & 0 & 26 \\
\hline \multicolumn{12}{|l|}{ Analysts } \\
\hline Positive effect & 2 & 1 & 2 & 1 & & & & & & & 6 \\
\hline \multirow[t]{2}{*}{ Mixed effect } & 1 & & & & & & & & & & 1 \\
\hline & 3 & 1 & 2 & 1 & 0 & 0 & 0 & 0 & 0 & 0 & 7 \\
\hline \multicolumn{12}{|c|}{ Information comparability } \\
\hline Positive effect & 1 & 1 & & & & & & & & & 2 \\
\hline \multirow[t]{2}{*}{ Mixed effect } & & 1 & & & & & & & & & 1 \\
\hline & 1 & 2 & 0 & 0 & 0 & 0 & 0 & 0 & 0 & 0 & 3 \\
\hline \multicolumn{12}{|l|}{ Information cost } \\
\hline \multirow[t]{2}{*}{ Negative effect } & & 1 & 1 & & & & 1 & & & & 3 \\
\hline & 0 & 1 & 1 & 0 & 0 & 0 & 1 & 0 & 0 & 0 & 3 \\
\hline \multicolumn{12}{|l|}{ Information use } \\
\hline \multirow[t]{2}{*}{ Positive effect } & & 2 & & & & & & & & & 2 \\
\hline & 0 & 2 & 0 & 0 & 0 & 0 & 0 & 0 & 0 & 0 & 2 \\
\hline Total & 26 & 16 & 8 & 7 & 3 & 2 & 2 & 1 & 1 & 1 & 67 \\
\hline
\end{tabular}

Most studies show empirical evidence of an effect of IFRS adoption that is positive (63\%) or mixed (21\%). Some of the studies showing there is a positive effect also provide evidence on a number of factors affec- ting this effect, particularly companies' characteristics, countries' characteristics, the way how IFRS are adopted (voluntary versus mandatory), or the differences between the local standards and IFRS. Evidence of a mi- 
xed effect are based on comprehensive samples (Europe and multicontinental) and, as a general rule, they demonstrate that IFRS have a positive effect only for some companies and/or countries. It is worth highlighting that the studies analyzing samples that include countries from different continents do not reach conclusions so categorical regarding mostly positive impacts in terms of consequences of IFRS adoption. For instance, as for the impact on information quality, it is noticed that 4 out of 6 studies using multicontinental samples detected null or mixed effects. If we analyzed only studies focusing on the EU, the conclusion might be different ( 5 show a positive effect and 2 a null effect).

Studies showing a negative effect analyze the effect of IFRS adoption on information cost, particularly in audit fees. In addition, only two studies (Lin et al., 2012; Ahmed, A. et al., 2013) showed a negative effect. Lin et al. (2012) analyzed a sample of German companies that, in 2005, stopped using U.S. GAAP to start using IFRS. It is not, therefore, an effect of the transition from national standards to IFRS.

Some studies also provide evidence of a null effect of IFRS adoption on information quality and the capital market. Nevertheless, these studies analyze, almost all of them, voluntary IFRS adoption within periods prior to 2002, by using Chinese (Ball et al., 2000) or German samples (Leuz, 2003; Van Tendeloo \& Vanstraelen, 2005;
Daske, 2006; Hung \& Subramanyam, 2007). Kabir et al. (2010) have analyzed the mandatory IFRS adoption in New Zealand and a more recent period (2002-2009), but the evidence of a null effect may be explained by a greater similarity between local standards and IFRS, when compared to local standards used in many countries.

So, we may conclude that negative or null effects of IFRS adoption are related to specific contexts. Particularly, it is crucial to recognize that it is likely that companies voluntarily adopting IFRS have significant differentiating characteristics when compared to those that do not, something which makes it impossible to generalize the results based on samples of companies that voluntarily adopt the standards and even to compare them to studies examining mandatory adoption (Pope \& McLeay, 2011; Soderstrom \& Sun, 2007; Palea, 2013).

In summary, most studies examine the effect of IFRS adoption on information quality and the capital markets, with a predominance of samples that include a large number of countries. The results indicate that, as a general rule, IFRS adoption has a positive effect, but it particularly depends on countries' characteristics (notably enforcement level) and companies' characteristics. Sharing rules is not, by itself, enough to create a common business language, and management incentives and institutional factors play a major role in framing the characteristics of financial reporting.

\section{FINAL REMARKS AND SUGGESTIONS FOR FURTHER RESEARCH}

Although existing research suggests that companies and users of financial information do benefit from IFRS adoption, the truth is that not all companies and not all users are benefited. As mentioned in the previous section, there are already some studies examining this issue, but much remains to be studied.

The scope of our study, which, unlike most of the literature reviews on the subject under analysis published so far by journals within the field, includes studies addressing the consequences of IFRS adoption in the EU and also in other geographic areas, enabled detecting that when using samples that include countries from different continents, the results are not as favorable to IFRS adoption when compared to samples that include only EU countries. On the other hand, when considering a wider range of consequences than the literature reviews published so far, this study is able to identify the types of such consequences concentrating the various kinds of effects.

This article showed that studies addressing voluntary IFRS adoption tend to find not positive effects, while studies that mainly examine mandatory IFRS adoption tend to provide evidence of positive effects. However, several authors inquire whether the effects on the capital market are, in fact, entirely attributable to IFRS adoption. For instance, Brüggemann et al. (2013) claim that the introduction of mandatory use of IFRS by all companies at a certain point implies a problem related to the difficulty of distinguishing the potential effect of IFRS adoption from the effects of other concomitant changes from which the effects under analysis are also derived.

Hail et al. (2010b) point out the need for carefully studying whether the effects that are attributed to IFRS adoption will not be the result of other economic factors at stake in a dynamic global economy. These authors stress the impossibility of assessing the effects of various regulatory scenarios (e.g. adopting U.S. GAAP in the EU instead of IFRS or, also in the EU, the existence of competition between sets of standards). From this perspective, Hail et al. (2010b), and we agree with them, suggest explicitly considering properly constructed counterfactuals.

It is also worth noticing, just as Christensen (2012) does, that research addressing IFRS adoption conducted to date clearly focuses on the benefits of adopting IFRS to the detriment of the costs of such adoption. Well, this kind of research may prove to be significant in determining the evolution of the IFRS adoption process in the U.S. 
Another aspect that seems particularly important to us that also has not been examined, yet, is related to whether the consequences of IFRS adoption are different depending on the kind of standards adoption. That is, are the consequences of adopting the standards, just as issued by the IASB, as it occurred, for instance, in the EU, different from the consequences of a convergence of national standards with IFRS, as it happened, for instance, in Australia?

Also important, in terms of what we are yet to know about the effects of IFRS adoption, is the almost total lack of knowledge about what is happening at the level of small companies, which derives from a strong bias for large companies included in the samples examined in most studies on the theme (Brüggemann et al., 2013). Thus, studies addressing the consequences at the level of small companies are crucial to properly inform decision-makers in terms of accounting standards.

There is also a lack of studies carefully examining whether companies adopt IFRS in fact, i.e. studies that analyze the degree of compliance with IFRS by companies and decisions having an accounting nature effectively made by them (Brüggemann et al., 2013). Only by means of studies on compliance, disclosure, and accounting choice that use manually collected data will enable determining whether financial reporting becomes, in fact, more transparent and comparable.

Among what we consider yet to be known there is also the effect of IFRS adoption by the EU on the IASB project's credibility (Pope \& McLeay, 2011). Will the consequences of IFRS adoption be different due to this increase in credibility?

One aspect that we have left to the end, but regarded as extremely significant, concerns the need to recognize that most of the studies published so far suffers from a problem related to the fact that it is quite likely that book values are tainted by the effects of IFRS 1: First-time adoption of IFRS (Brüggemann et al., 2013). Probably, in many cases, the actual consequences of IFRS adoption will begin to be detectable after several years applying these standards. Therefore, replication of studies already carried out may be an important way to consolidate, deepen, or invalidate existing knowledge on the theme under analysis in this article.

However, there are other issues worthy of further studies, among which there are the following:

- What is the effect and what is the relative importance of improving the quality and increasing the comparability of information derived from IFRS adoption on the credit market, the capital market, and the analysts' prediction amount and ability?

- Which are the companies having a more advantageous cost/benefit ratio?

- What is the role played by companies' incentives in the success of IFRS adoption in countries with a low enforcement level, when compared to countries with a high enforcement level?

- Which are the factors affecting the effect of IFRS adoption on accounting information use by managers?

- What is the effect of IFRS adoption on accounting information use by other users?

Studies that allow answering these and other questions that may arise are significant inputs for the process of adjusting and converging to a pattern of accounting standards to be universally applied.

\section{References}

Aharony, J., Barniv, R., \& Falk, H. (2010). The impact of mandatory IFRS adoption on equity valuation of accounting numbers for security. investors in the EU. European Accounting Review, 19, 535-578.

Ahmed, A., Neel, M., \& Wang, D. (2013). Does mandatory adoption of IFRS improve accounting quality? Preliminary evidence. Contemporary Accounting Research, 30(4), 1344-1372.

Ahmed, K., Chalmers, K., \& Khlif, H. (2013). A meta-analysis of IFRS adoption effects. International Journal of Accounting, 48, 173-217.

Armstrong, C. S., Barth, M. E., Jagolinzer, A. D., \& Riedl, E. J. (2010). Market reaction to the adoption of IFRS in Europe. The Accounting Review, 85(1), 31-61.

Ashbaugh, H., \& Pincus, M. (2001). Domestic accounting standards, International Accounting Standards, and the predictability of earnings. Journal of Accounting Research, 39(3), 417-434.

Atwood, T. J., Drake, M. S., Myers, J. N., \& Myers, L. A. (2011). Do earnings reported under IFRS tell us more about future earnings and cash flows? Journal of Accounting and Public Policy, 30(2), 103-121.

Aubert, F., \& Grudnitski, G. (2011). The impact and importance of mandatory adoption of International Financial Reporting Standards in Europe. Journal of International Financial Management and Accounting, 22, 1-26.

Ball, R. (2006). International financial reporting standards (IFRS): pros and cons for investors. Accounting and Business Research, 36(suplemento 1), 5-27.
Ball, R., Robin, A., \& Wu, J. S. (2000). Accounting standards, the institutional environment and issuer incentives: effect on timely loss recognition in China. Asia-Pacific Journal of Accounting and Economics, 7, 71-96.

Barth, M. E., Landsman, W. R., \& Lang, M. H. (2008). International Accounting Standards and accounting quality. Journal of Accounting Research, 46(3), 467-498.

Barth, M. E., Landsman, W. R., Lang, M., \& Williams, C. (2012). Are IFRSbased and US GAAP based accounting amounts comparable? Journal of Accounting and Economics, 54(1), 68-93.

Bissessur, S., \& Hodgson, A. (2012). Stock market synchronicity: an alternative approach to assessing the information impact of Australian IFRS. Accounting and Finance, 52, 187-212.

Bonner, S. E., Hesford, J. W.' Van der Stede, W. A., \& Young, S. M. (2006). The most influential journals in academic accounting. Accounting, Organizations and Society, 31(7), 663-685.

Brochet, F., Jagolinzer, A., \& Riedl, E. (2013). Mandatory IFRS adoption and financial statement comparability. Contemporary Accounting Résearch, 30(4), 1374-1400.

Brown. P. (2011). International Financial Reporting Standards: what are the benefits? Accounting and Business Research, 41(3), 269-285.

Brown, P. (2013). Some observations on research on the benefits to nations of adopting IFRS. The Japanese Accounting Review. doi:10.11640/ tjar.3.2013.01 
Brüggemann, U., Hitz, J.-M., \& Sellhorn, T. (2013). Intended and unintended consequences of mandatory IFRS adoption: a review of extant evidence and suggestions for future research: European Accounting Review, 22(1), 1-37.

Byard, D., Li, Y., \& Yu, Y. (2011). The effect of mandatory IFRS adoption on financial analysts' information environment. Journal of Accounting Research, 49(1), 69-96.

Calixto, L. (2010). Análise das pesquisas com foco nos impactos da adoção do IFRS em países europeus. Contabilidade Vista \& Revista, 21, 157187.

Chalmers, K., Clinch, G., \& Godfrey, J. M. (2008). Adoption of International Financial Reporting Standards: impact on the value relevance of intangible assets. Australian Accounting Review, 18(3), 237-247.

Chalmers, K., Clinch, G., Godfrey, J. M., \& Wei, Z. (2012). Intangible assets, IFRS and analysts' earnings forecasts. Accounting and Finance, 52, 691-721.

Chan, K. C., \& Liano, K. (2009). Threshold citation analysis of influential articles, journals, institutions and researchers in accounting. Accounting \& Finance, 49, 59-74.

Chen, H., Tang, Q., Jiang, Y., \& Lin, Z. (2010). The role of International Financial Reporting Standards in accounting quality: evidence from the European Union. Journal of International Financial Management and Accounting, 21, 220-278.

Chen, C., Young, D., \& Zhuang, Z. (2013). Externalities of mandatory IFRS adoption: evidence from cross-border spillover effects of financial information on investment efficiency. The Accounting Review, 88(3), 881-914.

Choi, Y., Peasnell, K., \& Toniato, J. (2013). Has the IASB been successful in making accounting earnings more useful for prediction and valuation? UK evidence. Journal of Business Finance and Accounting, 40(7), 741-768.

Christensen, H. B. (2012). Why do firms rarely adopt IFRS voluntarily? Academics find significant benefits and the cost appear to be low. Review of Accounting Studies, 17(3), 518-525.

Christensen, H., Hail, L., \& Leuz, C. (2013). Mandatory IFRS reporting and changes in enforcement. Journal of Accounting and Economics, 56, 147-177.

Christensen, H. B., Lee, E., \& Walker, M. (2009). Do IFRS reconciliations convey information? The effect of debt contracting. Journal of Accounting Research, 47, 1167-1199.

Clacher, I., Ricquebourg, A. D., \& Hodgson, A, (2013). The value relevance of direct cash flows under International Financial Reporting Standards. Abacus, 49(3), 367-395.

Cotter, J., Tarca, A., \& Wee, M. (2012). IFRS adoption and analyst's earnings forecasts: Australian evidence. Accounting and Finance, 52, 395-419.

Covrig, V., DeFond, M., \& Hung, M. (2007). Home bias, foreign mutual fund holdings, and the voluntary adoption of International Accounting Standards. Journal of Accounting Research, 45(1), 41-70.

Daske, H. (2006). Economic benefits of adopting IFRS or US-GAAP: have the expected cost of equity capital really decreased? Journal of Business Finance and Accounting, 33(3-4), 329-373.

Daske, H., \& Gebhardt, G. (2006). International Financial Reporting Standards and experts' perceptions of disclosure quality. Abacus, 42(34), 461-98.

Daske, H., Hail, L., Leuz, C., \& Verdi, R. S. (2008). Mandatory IFRS reporting around the world: early evidence on the economic consequences. Journal of Accounting Research, 46(5), 1085-1142.

Daske, H., Hail, L., Leuz, C., \& Verdi, R. (2013). Adopting a label: heterogeneity in the economic consequences around IAS/IFRS adoptions. Journal of Accounting Research, 51, 495-547.

DeFond, M., Hu, X., Hung, M., \& Li, S. (2011). The impact of IFRS adoption on foreign mutual fund ownership: the role of comparability. Journal of Accounting and Economics, 51(3), 240-258

De George, E. T., Ferguson, C. B., \& Spear, N. A. (2013). How much does IFRS cost? IFRS adoption and audit fees. The Accounting Review, $88(2), 429-462$.

Devalle, A., Onali, E., \& Magarini, R. (2010). Assessing the value relevance of accounting data after the introduction of IFRS in Europe. Journal of International Financial Management and Accounting, 21, 85-119.

Florou, A., \& Pope, P. F. (2012). Mandatory IFRS adoption and institutional investment decisions. The Accounting Review, 87(6), 1993-2025.

Frino, A., Palumbọ, R., Capalbo, F., Gerace, D., \& Mollica, V. (2013). Information disclosure and stock liquidity: evidence from Borsa
Italiana Abacus, 49(4), 423-440.

Gebhardt, G., \& Novotny-Farkas, Z. (2011). The effects of IFRS adoption on the financial reporting quality of European banks. Journal of Business Finance and Accounting, 38(3-4), 289-333

Glaum, M., Baetge, J., Grothe, A., \& Oberdörster, T. (2013). Introduction of International Accounting Standards, disclosure quality and accuracy of analysts' earnings forecasts. European Accounting Review, 22(1), 79-116.

Gordon, L. A., Loeb, M. P., \& Zhu, W. (2012). The impact of IFRS adoption on foreign direct investment. Journal of Accounting and Public Policy, 31(4), 374-398

Gray, S. J., Linthicum, C. L., \& Street, D. L. (2009). Have 'European' and US GAAP measures of income and equity converged under IFRS? Evidence from European companies listed in the US. Accounting and Business Research, 39(5), 431-447.

Griffin, P. A., Lont, D. H., \& Sun, Y. (2009). Governance regulatory changes, International Financial Reporting Standards adoption, and -New Zealand audit and non-audit fees: empirical evidence. Accounting and Finance, 49, 697-724

Hail, L., Leuz, C., \& Wysocki, P. (2010a). Global accounting convergence and the potential adoption of IFRS by the U.S. (part I). Accounting Horizons, 24(3), 355-394.

Hail, L., Leuz, C., \& Wysocki, P. (2010b). Global accounting convergence and the potential adoption of IFRS by the U.S. (part II). Accounting Horizons, 24(4), 567-588.

Hong, H. (2013). Does mandatory adoption of International Financial Reporting Standards decrease the voting Premium for dual-class shares? Accounting Review, 88(4), 1289-1325.

Horton, J., \& Serafeim, G. (2010). Market reaction and valuation of IFRS reconciliation adjustments: first evidence from the UK. Review of Accounting Studies, 15(4), 725-751.

Horton, J., Serafeim, G., \& Sèrafeim, I. (2013). Does mandatory IFRS adoption improve the information environment? Contemporary Accounting Research, 30, 388-423.

Hung, M., \& Subramanyam, K. R. (2007). Financial statement effects of adopting international accounting standards: the case of Germany. Review of Accounting Studies, 12(4), 623-657.

Jeanjean, T., \& Stolowy, H. (2008). Do accounting standards matter? An exploratory analysis of earnings management before and after IFRS adoption. Journal of Accounting and Public Policy, 27(6), 480-494.

Jermakowicz, E. K., Prather-Kinsey, J., \& Wulf, I. (2007). The value relevance of accounting income reported by DAX-30 German companies. Journal of International Financial Management and Accounting, 18(3), 151-191.

Joos, P. P. M., \& Leung, E. (2013). Investor perceptions of potential IFRS adoption in the United States. The Accounting Review, 88(2), 577-609.

Kabir, M. H., Laswad. F., \& Ainul Islam, M. (2010). Impact of IFRS in New Zealand on accounts and earnings quality. Australian Accounting Review, 20(4), 343-357.

Karamanou, I., \& Nishiotis, G. P. (2009). Disclosure and the cost of capital: evidence from the market's reaction to firm voluntary adoption of IAS. Journal of Business Finance and Accounting, 36, 793-821.

Kaya, D., \& Pillhofer, J. A. (2013). Potential adoption of IFRS by the United States: a critical view. Accounting Horizons, 27(2), 271-299.

Khurana, I., \& Michas, P. (2011). Mandatory IFRS adoption and the U.S home bias. Accounting Horizons, 25(4), 729-753.

Kim, J.-B., \& Shi, H. (2012). IFRS reporting, firm-specific information flows, and institutional environment: international evidence. Review of Accounting Studies, 17(3), 474-517.

Kim, J.-B., Liu, X., \& Zheng, L. (2012). The impact of mandatory IFRS adoption on audit fees: theory and evidence. The Accounting Review, 87(6), 2061-2094

Kim, J.-B., Tsui, J. S. L., \& Yi, C. H. (2011). The voluntary adoption of International Accounting Standards and loan contracting around the world. Review of Accounting Studies, 16(4), 779-811.

Landsman, W. R., Maydew, E. L., \& Thornock, J. R. (2012). The information content of annual earnings announcements and mandatory adoption of IFRS. Journal of Accounting and Economics, 53(1-2), 34-54.

Lara, J. M. G., Torres, J. A. R., \& Veira, P. J. V. (2008). Conservatism of earnings reported under International Accounting Standards: a comparative study. Spanish Journal of Finance and Accounting, $37(138), 197-210$

Leuz, C. (2003). IFRS versus US GAAP: information asymmetry-based evidence from Germany's new market. Journal of Accounting Research, 41.(2), 445-472 
Leuz, C. (2010). Different approaches to corporate reporting regulation: how jurisdictions differ and why. Accounting and Business Research, 40(3), 229-256

Li, S. (2010). Does mandatory adoption of International Financial Reporting Standards in the European Union reduce the cost of equity capital? The Accounting Review, 85(2), 607-636.

Lin, S., Riccardi, W., \& Wang, C. (2012). Does accounting quality change following a switch from U.S. GAAP to IFRS? Evidence from Germany. Journal of Accounting and Public Policy, 31(6), 641-657.

Ling-Ching, A., Hsu, A., \& Lee, E. (2013). Does mandatory IFRS adoption affect the credit ratings of foreign firms cross-listed in the U.S.? Accounting Horizons, 27(3), 491-510.

McAnally, M., McGuire, S., \& Weaver, C. (2010). Assessing the financial reporting consequences of conversion to IFR่S: the case of equitybased compensation. Accounting Horizons, 24(4), 589-621.

Morais, A., \& Curto, J. D. (2009). IASB standards adoption: value relevance and the influence of country-specific factors. Australian Accounting. Review, 19(2), 128-143.

Niskanen, J., Kinnunen, J., \& Kasanen, E. (2000). The value relevance of IAS reconciliation components: empirical evidence from Finland. Journal of Accounting and Public Policy, 19(2), 119-137.

Ozkan, N., Singer, Z., \& You, H. (2012). Mandatory IFRS adoption and the contractual usefulness of accounting information in executive compensation. Journal of Accounting Research, 50(4), 1077-1107.

Palea, V. (2013). IAS/IFRS and financial reporting quality; lessons from the European experience. China Journal of Accounting Research, 6(4), 247-263.

Parker, L. D., \& Guthrie, J. (2013). Accounting scholars and journals rating and benchmarking: risking academic research quality. Accounting, Auditing \& Accountability Journal, 26(1), 4-15.

Platikanova, P., \& Perramon, J. (2012). Economic consequences of the first-time IFRS introduction in Europe, Spanish Journal of Finance and Accounting, 156, 497-519.

Pope, P. F., \& McLeay, S. J. (2011). The European IFRS experiment: objectives, research challenges and some early evidence. Accounting and Business Research, 41(3), 233-266

Securities and Exchange Commission. (2007). Acceptance from foreign private issuers of financial statements prepared in accordance with International Financial Reporting Standards without reconciliation to US GAAP. Recuperado de www.sec.gov/rules/final/2007/33-8879.pdf
Securities and Exchange Commission. (2008). Proposed rule: roadmap for the potential use of financial statements prepared in accordance with International Financial Reporting Standards by U.S. issuers. Recuperado de http://www.sec.gov/rules/proposed/2008/33-8982.pdf

Shima, K. M., \& Gordon, E. A. (2011). IFRS and the regulatory environment: the case of U.S. investor allocation choice. Journal of Accounting and Public Policy, 30(5), 481-500.

Soderstrom, N., \& Sun, K. (2007). A review of the accounting quality after IFRS adoption in the European Union. European Accounting Review, 16(4), 675-702

Sun, J., Cahan, S., \& Emanuel, D. (2011). How would the mandatory adoption of IFRS affect the earnings quality of U.S. firms? Evidence from cross-listed firms in the U.S. Accounting Horizons, 25(4), 837860.

Tan, H., Wang, S., \& Welker, M. (2011)..Analyst following and forecast accuracy after mandated IFRS adoptions. Journal of Accounting Research, 49(5), 1307-1357.

Taylor, G., \& Tower, G. (2011). Determinants of financial ratio disclosure patterns of Australian listed extractive companies: Australian Accounting Review, 21, 302-314.

Taylor, G., Tower, G., \& Neilson, J. (2010). Corporate communication of financial risk. Accounting and Finance, 50, 417-446.

Van Tendeloo, B., \& Vanstraelen, A. (2005). Earnings management under German GAAP versus IFRS. The European Accounting Review, 14(1), $155-180$

Yip, R. W. Y., \& Young, D. (2012). Does mandatory IFRS adoption improve information comparability? The Accounting Review, 87(5), 1767-1789.

Zeff, S. A., \& Nobes, C. W. (2010). Commentary: has Australia (or any other jurisdiction) 'adopted' IFRS? Australian Accounting Review, 53(20), 178-184.

Correspondence Address:

Isabel Lourenço

Instituto Universitário de Lisboa

Avenida das Forças Armadas, 1649-026, Lisboa

E-mail: isabel.lourenco@iscte.pt 